Supplement of Ocean Sci., 14, 543-562, 2018

https://doi.org/10.5194/os-14-543-2018-supplement

(C) Author(s) 2018. This work is distributed under

the Creative Commons Attribution 4.0 License.

(c) (1)

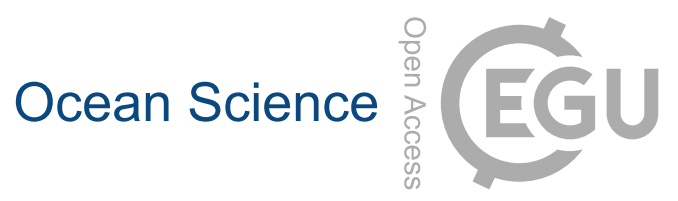

Supplement of

\title{
Characteristics of chromophoric and fluorescent dissolved organic matter in the Nordic Seas
}

\author{
Anna Makarewicz et al. \\ Correspondence to: Anna Makarewicz (araczkowska@iopan.gda.pl)
}

The copyright of individual parts of the supplement might differ from the CC BY 4.0 License. 


\section{Supplementary information}

The water identification was based on Rudels at al. (2005) with the modifications noted in Table S1. In general we assumed that water characterized by density, potential temperature and salinity found south of $74 \mathrm{~N}$ parallel could not be regard as PSW or PSWW due strong influence of high temperature on density.

Table S1. Water masses definition by Rudels et al. (2005) with modifications and remarks.

\begin{tabular}{|c|c|c|c|c|c|c|c|}
\hline \multirow[b]{2}{*}{ Water Masses } & \multicolumn{3}{|c|}{ Rudels at al. (2005) } & \multicolumn{3}{|c|}{ Modifications } & \multirow[b]{2}{*}{ Remarks } \\
\hline & Symbol & $\Theta\left[{ }^{\circ} \mathrm{C}\right]$ & $\sigma_{\theta}\left[\mathrm{kg}^{*} \mathrm{~m}^{-3}\right]$ & S & Lat $[\mathrm{N}]$ & $\mathrm{D}[\mathrm{m}]$ & \\
\hline \multirow[t]{3}{*}{ Atlantic Water } & AW & $>2$ & $27.7<\sigma_{\theta} \leq 27.97$ & & & & \\
\hline & AW & $>0$ & $\begin{array}{l}27.97<\sigma_{\theta} \\
\sigma_{0.5} \leq 30.44\end{array}$ & & & & \\
\hline & AW & $>0$ & $\leq 27.7$ & $>34.9$ & & & $\begin{array}{l}\text { This part was separated from } \\
\text { PSWw on the basis of high } \\
\text { salinity >34.9. It covers the } \\
\text { Atlantic domain where low } \\
\text { density is caused by high } \\
\text { temperatures }\end{array}$ \\
\hline $\begin{array}{l}\text { Polar Surface } \\
\text { Water }\end{array}$ & PSW & $\leq 0$ & $\leq 27.7$ & & $>74$ & & $\begin{array}{l}\text { Assumption that PSW does } \\
\text { not occur south of } 74 \mathrm{~N}\end{array}$ \\
\hline $\begin{array}{l}\text { Polar Surface } \\
\text { Water warm } \\
\end{array}$ & PSWw & $>0$ & $\leq 27.7$ & $\leq 34.9$ & $>74$ & $\leq 50$ & $\begin{array}{l}\text { Assumption that PSW does } \\
\text { not occur south of } 74 \mathrm{~N} \text {, and } \\
\text { surface water occur in first } 50 \\
\mathrm{~m}\end{array}$ \\
\hline $\begin{array}{l}\text { Arctic Atlantic } \\
\text { Water }\end{array}$ & AAW & $\begin{array}{l}0< \\
\mathrm{x} \leq 2\end{array}$ & $27.7<\sigma_{\theta} \leq 27.97$ & & & & \\
\hline Deep water & $\begin{array}{l}\text { DW(AI } \\
\text { W) }\end{array}$ & $\leq 0$ & $\begin{array}{l}27.97<\sigma_{\theta} \\
\sigma_{0.5} \leq 30.44\end{array}$ & & & & $\begin{array}{l}\text { All waters classified as AIW } \\
\text { in AREX cruises occur close } \\
\text { to the bottom. }\end{array}$ \\
\hline
\end{tabular}

Table S1: The results of $\mathrm{T}$ test with variables grouped by year and water masses. Table results of t-test that measure significance in differences in mean value. The difference between variable averages in selected layer are significant if significance level $p<0.05$. NS - not significant, $\mathrm{S}$ - significant differences (bold text).

\begin{tabular}{|c|c|c|c|c|c|c|}
\hline Variable & Year & Water masses & $\mathrm{t}$-value & $\mathrm{df}$ & $\mathrm{p}$ & Significance \\
\hline \multirow{9}{*}{$\mathrm{a}_{\mathrm{CDOM}}(350)$} & \multirow[t]{3}{*}{2013} & AW vs. PSW & 0.077730 & 44 & 0.938395 & NS \\
\hline & & AW vs. PSWw & -1.55385 & 74 & 0.124487 & NS \\
\hline & & PSW vs. PSWw & -0.484689 & 34 & 0.631005 & NS \\
\hline & \multirow[t]{6}{*}{2014} & AW vs. PSW & 1.057659 & 176 & 0.291660 & NS \\
\hline & & AW vs. PSWw & -0.057183 & 200 & 0.954456 & NS \\
\hline & & AW vs. AAW & -0.084527 & 176 & 0.932733 & NS \\
\hline & & AW vs. IW/DW & -1.31413 & 183 & 0.190446 & NS \\
\hline & & PSW vs. PSWw & -1.20685 & 30 & 0.236920 & NS \\
\hline & & PSW vs. AAW & -1.16764 & 6 & 0.287250 & NS \\
\hline
\end{tabular}




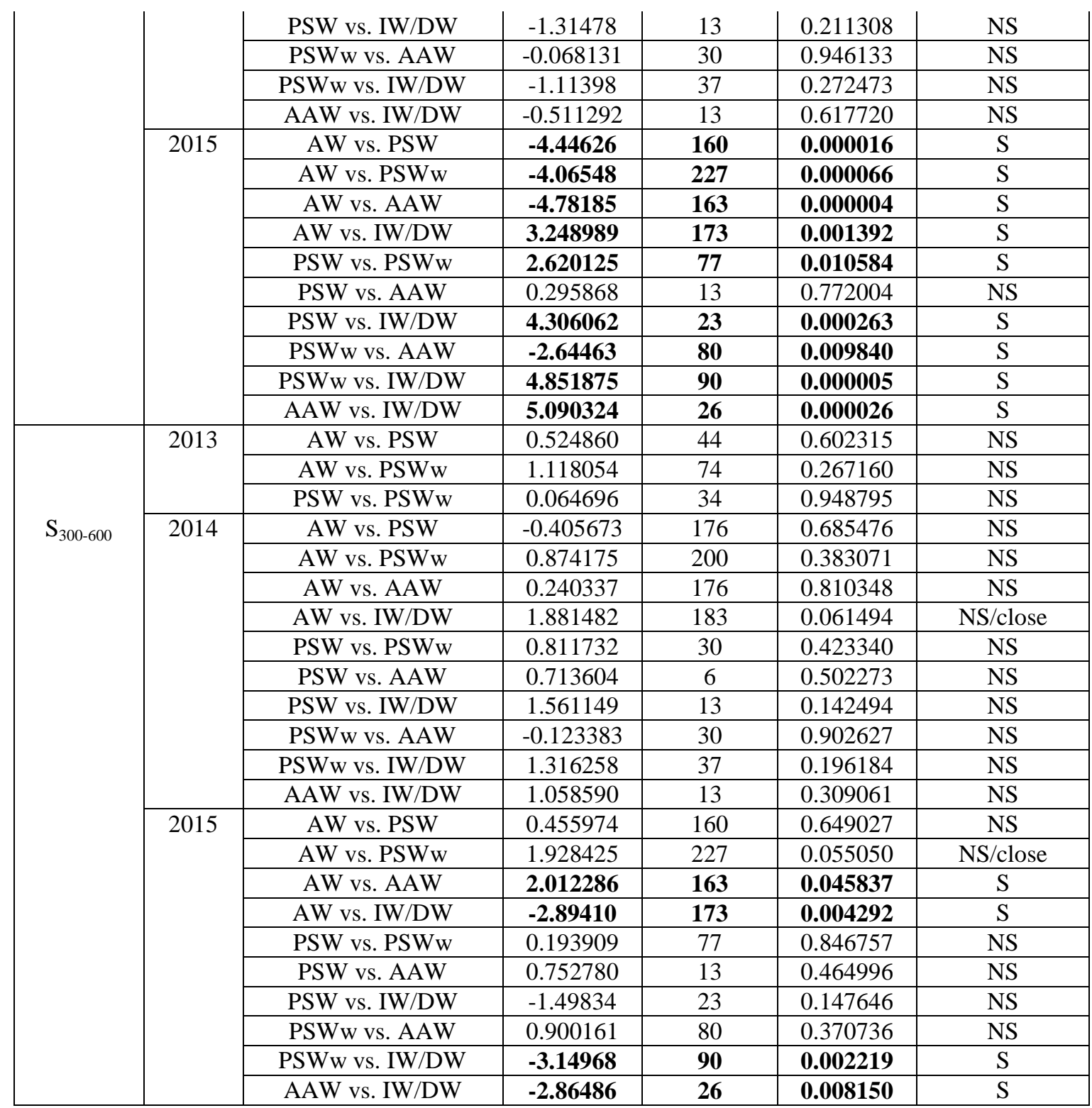

Table S3: The results of $\mathrm{T}$ test with variables grouped by water masses and year. Table list results of t-test that measure significance in differences in mean value. The difference between variable averages in selected layer are significant if significance level $p<0.05$. NS not significant, $\mathrm{S}$ - signify cant differences (bold text).

\begin{tabular}{|c|c|c|c|c|c|c|}
\hline Variable & Water mass & Year & t-value & $\mathrm{df}$ & $\mathrm{p}$ & Significance \\
\hline \multirow{9}{*}{$\mathrm{a}_{\mathrm{CDOM}}(350)$} & \multirow[t]{3}{*}{ AW } & 2013 vs. 2014 & 13.20111 & 215 & 0.000000 & $S$ \\
\hline & & 2013 vs. 2015 & 11.62407 & 197 & 0.000000 & $S$ \\
\hline & & 2014 vs. 2015 & -5.97262 & 328 & 0.000000 & $S$ \\
\hline & \multirow[t]{3}{*}{ PSW } & 2013 vs. 2014 & 6.162425 & 5 & 0.001638 & $\mathrm{~S}$ \\
\hline & & 2013 vs. 2015 & 0.254644 & 7 & 0.806317 & NS \\
\hline & & 2014 vs. 2015 & -3.16292 & 8 & 0.013336 & $\mathrm{~S}$ \\
\hline & PSWw & 2013 vs. 2014 & 5.540343 & 59 & 0.000001 & $S$ \\
\hline & & 2013 vs. 2015 & 5.685240 & 104 & 0.000000 & $S$ \\
\hline & & 2014 vs. 2015 & -5.42899 & 99 & 0.000000 & $\mathrm{~S}$ \\
\hline
\end{tabular}




\begin{tabular}{|c|c|c|c|c|c|c|}
\hline & AAW & 2014 vs. 2015 & -3.05781 & 11 & 0.010894 & $\mathrm{~S}$ \\
\hline & IW/DW & 2014 vs. 2015 & 1.086729 & 28 & 0.286424 & NS \\
\hline \multirow{11}{*}{$\mathrm{S}_{300-600}$} & \multirow{3}{*}{ AW } & 2013 vs. 2014 & -5.34852 & 215 & 0.000000 & $\mathrm{~S}$ \\
\hline & & 2013 vs. 2015 & -4.23678 & 197 & 0.000035 & $\mathrm{~S}$ \\
\hline & & 2014 vs. 2015 & 6.410876 & 328 & 0.000000 & $\mathrm{~S}$ \\
\hline & \multirow[t]{3}{*}{ PSW } & 2013 vs. 2014 & -1.99294 & 5 & 0.102863 & NS \\
\hline & & 2013 vs. 2015 & -0.817157 & 7 & 0.440760 & $\mathrm{NS}$ \\
\hline & & 2014 vs. 2015 & 1.788011 & 8 & 0.111578 & NS \\
\hline & PSWw & 2013 vs. 2014 & -3.98031 & 59 & 0.000191 & $\mathrm{~S}$ \\
\hline & & 2013 vs. 2015 & -2.50249 & 104 & 0.013890 & $S$ \\
\hline & & 2014 vs. 2015 & 3.544709 & 99 & 0.000602 & $\mathrm{~S}$ \\
\hline & AAW & 2014 vs. 2015 & $\mathbf{3 . 0 4 5 3 2 5}$ & 11 & 0.011140 & $\mathrm{~S}$ \\
\hline & IW/DW & 2014 vs. 2015 & -1.30430 & 28 & 0.202751 & $\mathrm{NS}$ \\
\hline
\end{tabular}

Significant difference between averaged $\mathrm{a}_{\mathrm{CDOM}}(350)$ values in classified water masses were observed only in 2015 except of PSW vs. AAW with a low number of samples. Similarly, significantly different average slope values were observed in 2015 for four sets of water masses pairs. The interannual differences in averages values of $\mathrm{a}_{\mathrm{CDOM}}(350)$ were insignificant (p>0.05) in PSW for 2013 and 2015 and in IW/DW in 2014 and 2015. All other pairs of interannual differences for distinct water masses were significant. In case of S300600 average values interannual differences were significant in all AW, PSWw and AAW. In the other hand PSW and IW/DW average values with a low number of samples were insignificant interannually.

The example of excitation-emission matrix (EEM) from AREX expedition with marked ex/em region for three channels of Wet Star Wet Lab CDOM fluorometer is presented (Figure S1). Coble (1996) specific peak areas: the humic-like 'A' region at $260 \mathrm{~nm}$ excitation (ex) and 380-460 nm emission (em); terrestrial fulvic ' $C$ ' region ex: at $350 \mathrm{~nm}$ and em: in range $420-480 \mathrm{~nm}$; marine humic-like ' $M$ ' region ex: at $312 \mathrm{~nm}$ and em: in range 380 $420 \mathrm{~nm}$; and the tryptophan-like or protein-like ' $\mathrm{T}$ ' region ex: at $275 \mathrm{~nm}$ and em: in range $340 \mathrm{~nm}$ were marked on Figure S1. This allowed for association of channels with different excitation/emission characteristics with specific peak areas as given in Coble (1996): Channel 1 (CH1), ex./em. 310/450 nm, represents marine ultraviolet humic-like peak $\mathrm{C}$ and marine humic-like peak M; Channel 2 (CH2), ex./em. 280/450 nm, represents UVC terrestrial humic-like peak A; and Channel $3(\mathrm{CH} 3)$, ex./em. 280/350 nm, represents the protein-like tryptophane peak T (Figure S1). 


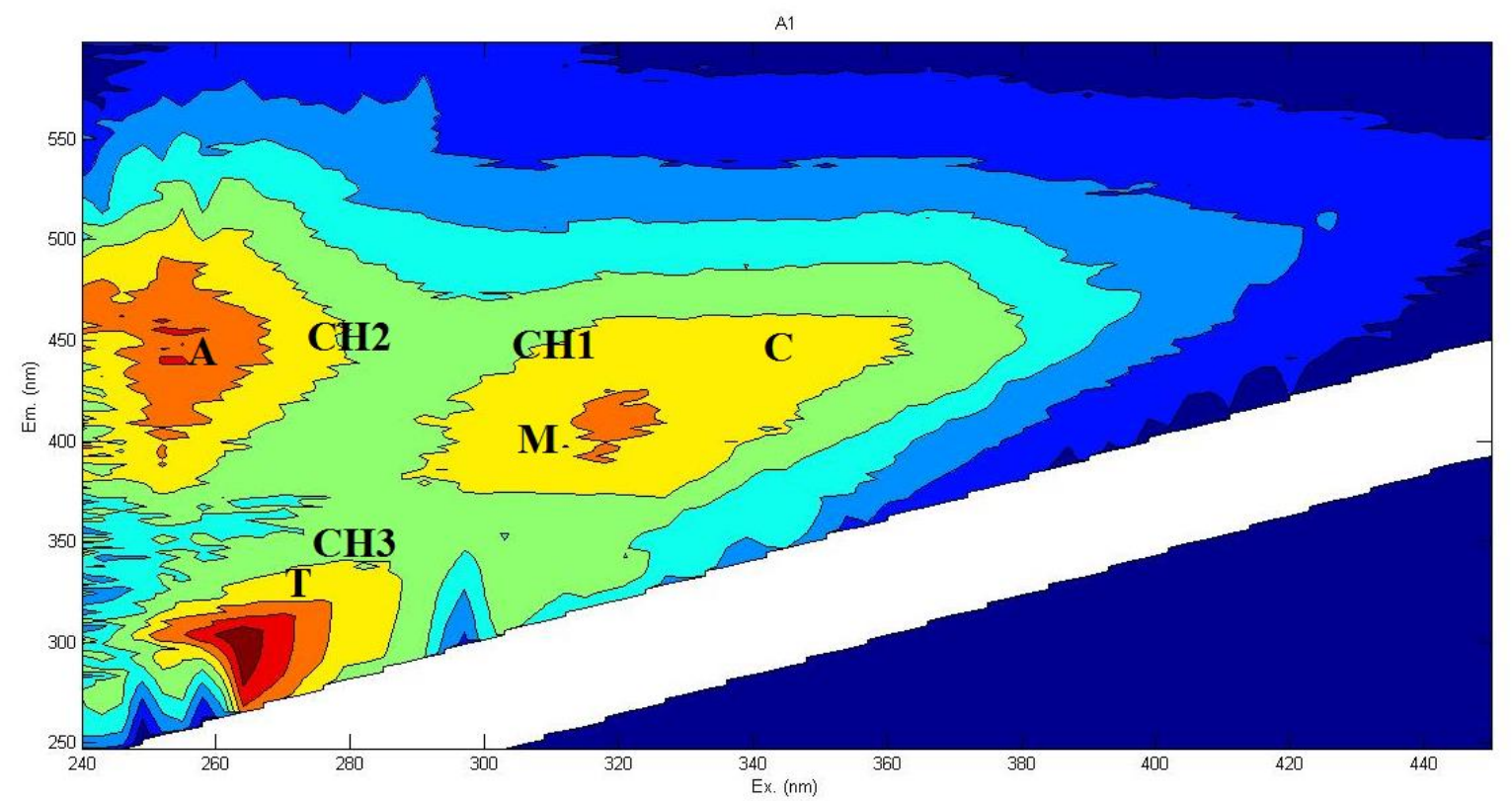

Figure S1: Typical example of excitation-emission matrix (EEM) from AREX expedition with marked ex/em region for three channels of Wet Star Wet Lab CDOM fluorometer (Channel 1 (CH1), ex./em. 310/450 nm, Channel 2 (CH2), ex./em. 280/450 nm,; Channel 3 (CH3), ex./em. 280/350 nm) together with Coble's specific EEM regions which characterize different sources of FDOM (the humic-like 'A' region at $260 \mathrm{~nm}$ excitation (ex) and $380-460 \mathrm{~nm}$ emission (em); terrestrial fulvic ' $C$ ' region at $350 \mathrm{~nm}$ ex and $420-480 \mathrm{~nm}$ em; marine humic-like ' $M$ ' region at $312 \mathrm{~nm}$ ex and 380-420 nm em; and the tryptophanlike or protein-like ' $\mathrm{T}$ ' region at $275 \mathrm{~nm}$ ex and $340 \mathrm{~nm}$ em.

The distribution of fluorescence intensity of the terrestrial humic-like FDOM $\left(I_{\mathrm{CH} 2}\right)$, and $\mathrm{SUVA}_{254}$ (ratio $\mathrm{a}_{\mathrm{CDOM}} 254$ and DOC) in the TS diagram was shown in Figure S2. The highest terrestrial humic-like FDOM values were observed in PSW and part of PSWw in depth range $15-50 \mathrm{~m}$. The lowest $I_{\mathrm{CH} 2}$ values were found in surface layer of PSWw and there was a large variability in AW (Figure S2a). There was a large variability and no consistent trends in distribution of $\mathrm{SUVA}_{254}$ values in different water masses in the study area, as shown in the TS diagram (Figure S2c). 
a)

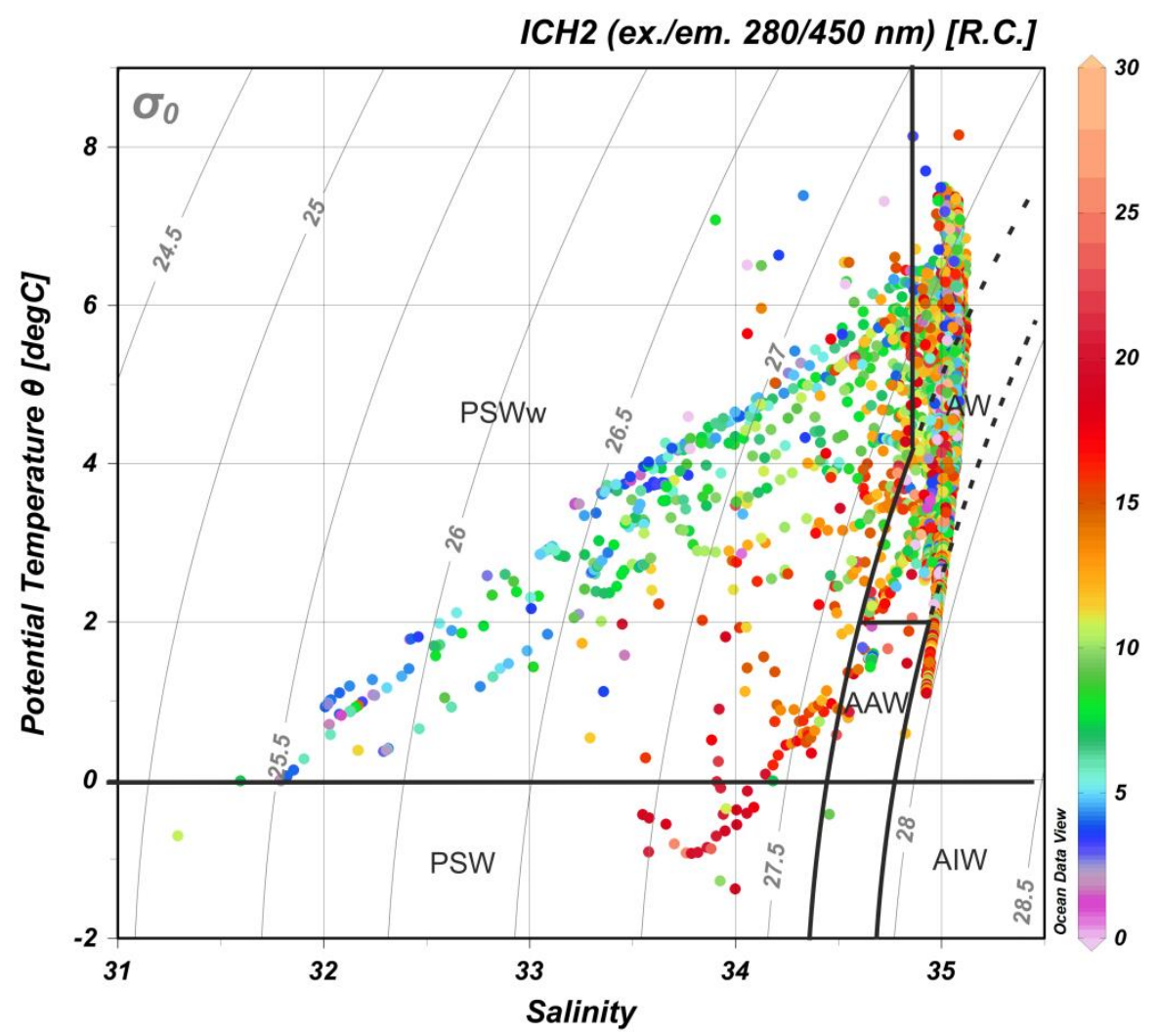

b)

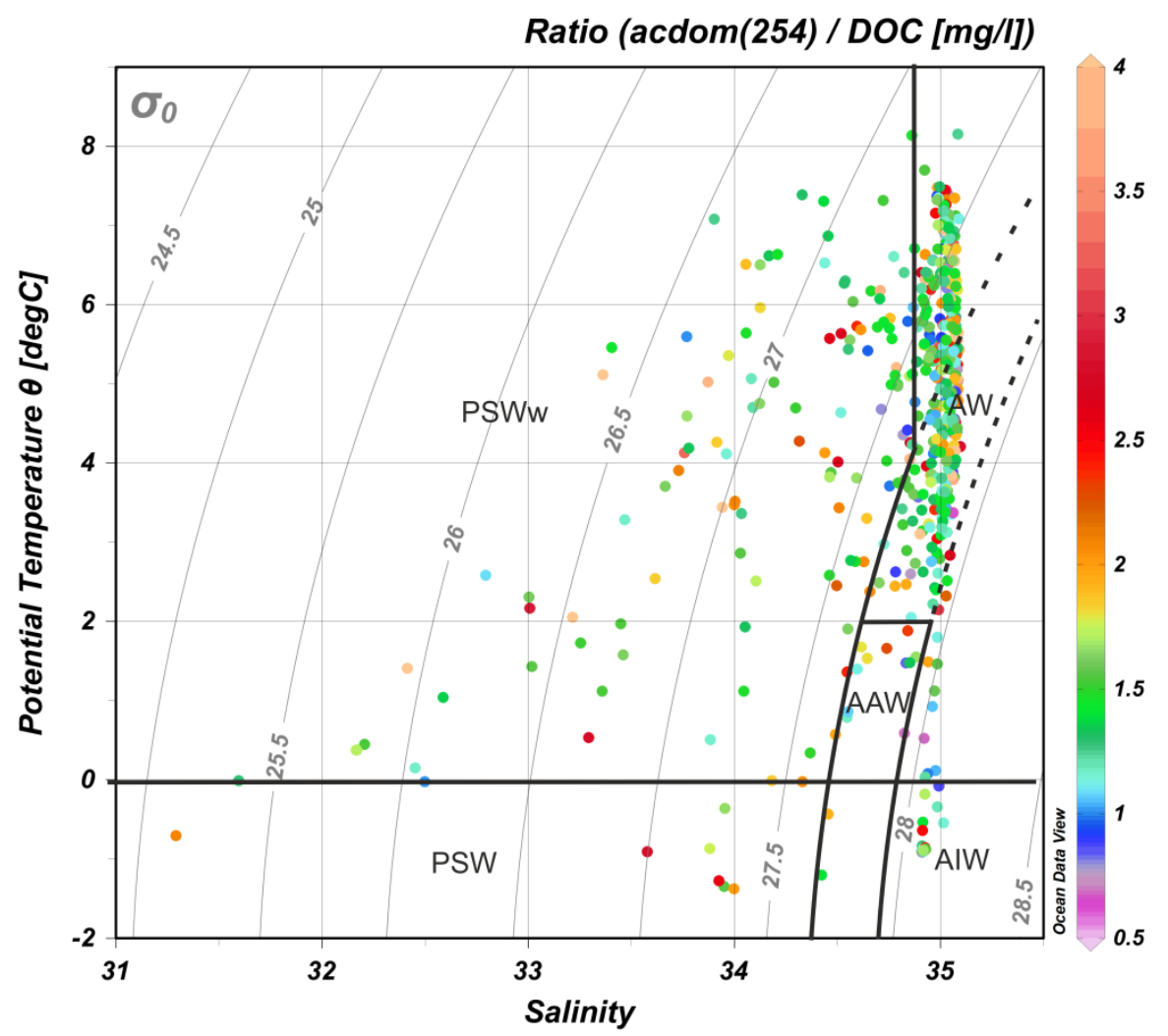


Figure S2: TS diagram of water mass distribution on the study 2013-2015. A) color represents terrestrial humic-like fraction fluorescence intensity $I_{\mathrm{CH} 2}$, ( ex./em. 280/450 nm, [RC]). B) color bar represents values of carbon specific CDOM absorption coefficient at 254 $\mathrm{nm}, \mathrm{SUVA}_{254}\left[\mathrm{~m}^{2} \mathrm{gC}^{-1}\right]$. The lower number of points in B) resulted from fewer number of discrete water samples for determination of CDOM. Water masses: AW (Atlantic Water), AAW (Arctic Atlantic Water), AIW (Arctic Intermediate Water), PSW (Polar Surface Water), PSWw (Polar Surface Water warm). Three areas noted as AW follow the three sets of conditions that define AW (see Table S1).

We presented the relationship between absorption coefficient at 676 and stimulated chlorophyll a fluorescence in 2014 and 2015 in the selected water masses to prove that measurements were not biased by instrument offset . The stability of chlorophyll $a$ intensity output was assessed by regressing the measured fluorescence intensity values against calibrated values of total absorption coefficient non-water at $676 \mathrm{~nm}, a_{\mathrm{tot}-\mathrm{w}}(676)$ in selected water masses. Value of the $a_{\mathrm{tot}-\mathrm{w}}(676)$ is a good proxy of the chlorophyll $a$ concentration (Roesler and Barnard, 2013). There was very good linear relationship between $I_{\text {FChla }}$ and $a_{\text {tot- }}$ ${ }_{\mathrm{w}}(676)$ in selected water masses in 2014 and 2015 with no visible offset in $I_{\text {FChla, }}$, values in both years ensuring negligible time drift in MicroFlu-Chl output (Figure S3). The difference in the in the $I_{\text {FChla }}$, and $a_{\text {tot-w }}(676)$ vertical distribution near the ocean surface in AW, shown on Figure 4, could in part be explained by a decrease in the fluorescence quantum yield by phytoplankton photoinhibition resulting from the stronger irradiance near the surface (Cullen, 1982). 

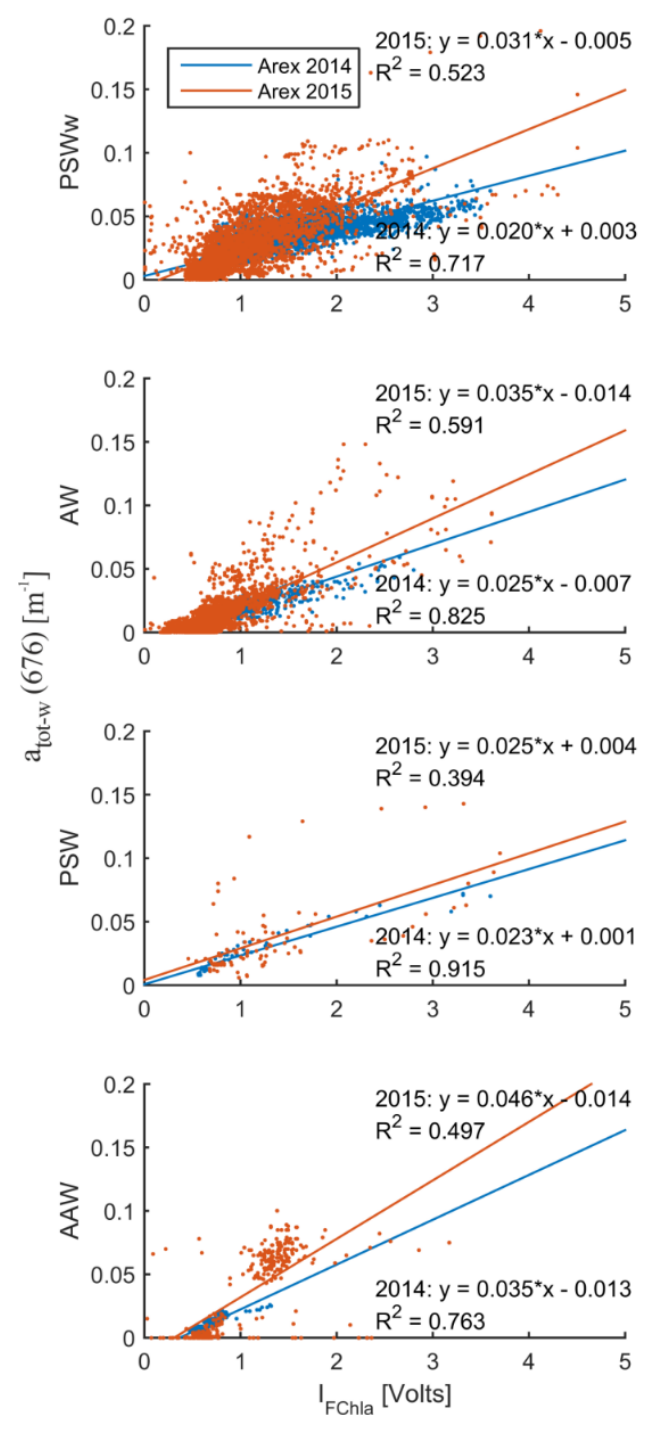

Figure S3: Relationship between total absorption coefficient non-water at $676 \mathrm{~nm}$ $\left(a_{\text {tot-w }}(676)\right.$ and stimulated chlorophyll a fluorescence $\left(\mathrm{I}_{\mathrm{FChla}}\right)$ in different water masses in 2014 and 2015.

According to Roesler and Barnard (2013) chlorophyll a concentration can be very well approximated by $a_{\text {tot-w }}(676)$. The very good correlation between $I_{F C h l a}$ and $a_{\text {tot-w }}(676)$ in selected water masses shown on Figure S3, as well together with very good correlation between $I_{\mathrm{CH} 3}$ and $I_{F C h l a}$ suggested a direct dependence between $I_{\mathrm{CH} 3}$ and $a_{\mathrm{tot}-\mathrm{w}}(676)$. There was a significant correlation between $I_{\mathrm{CH} 3}$ and $a_{\mathrm{tot}-\mathrm{w}}(676)$ as summarized on the Figure S4. This was another evidence confirming strong contribution of phytoplankton dynamics to spatial and temporal variability of FDOM protein-like fraction in Nordic Seas. 

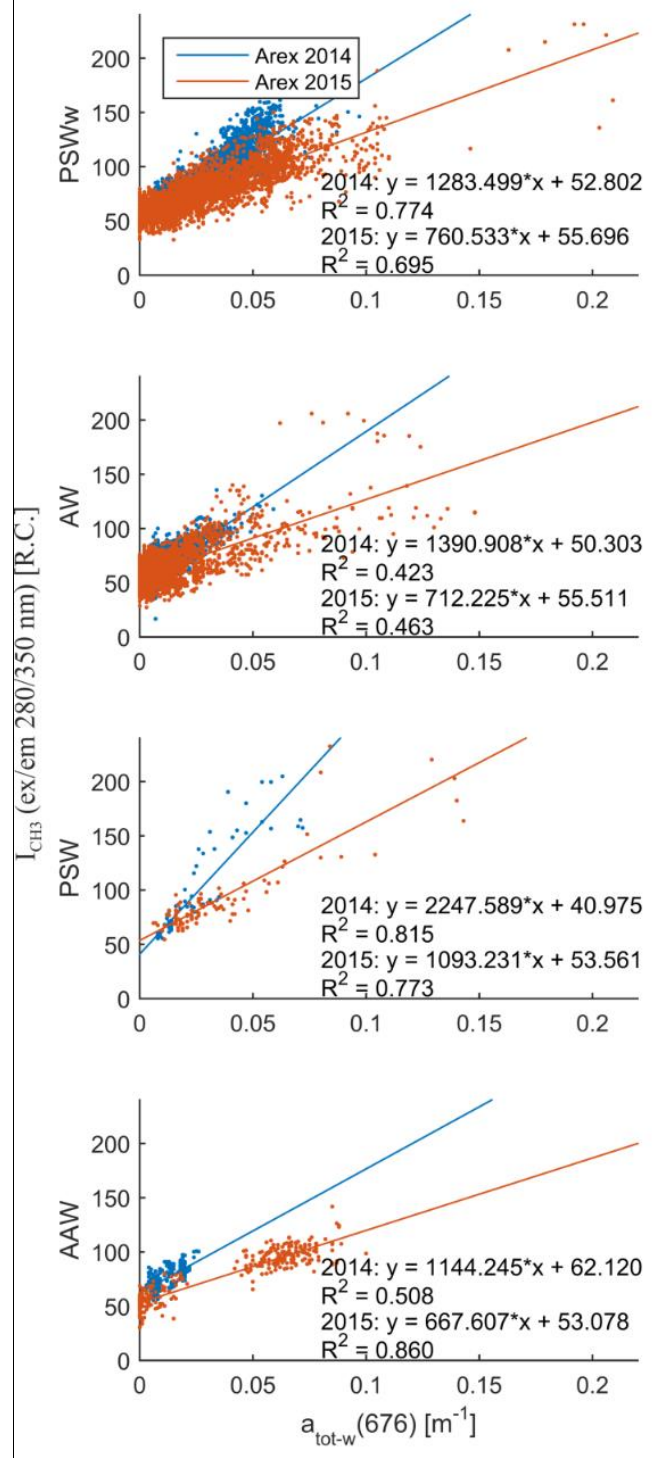

Figure S4: Relationship between fluorescence intensity of the protein-like component $\left(I_{\mathrm{CH} 3}\right)$ and particulate absorption coefficient at $676\left(a_{\mathrm{tot}-\mathrm{w}}(676)\right)$ in different water masses in 2014 and 2015.

\section{References:}

Coble, P. G.: Characterization of marine and terrestrial DOM in seawater using excitationemission matrix spectroscopy, Mar. Chem., 51(4), 325-346, 1996.

Cullen, J. J.: The Deep Chlorophyll Maximum: Comparing Vertical Profiles of Chlorophyll a, Canadian Journal of Fisheries and Aquatic Sciences, 39(5), 791-803, 1982.

Roesler, C. S. and Barnard A. H.: Optical proxy for phytoplankton biomass in the absence of photophysiology: Rethinking the absorption line height, Methods Oceanogr, 7, 79-94. doi:10.1016/j.mio.2013.12.003, 2013. 